\title{
Impacts of an invasive alien Proteaceae on native plant species richness and vegetation structure
}

\author{
Laimi Erckie $^{\mathrm{a}}$, Opeyemi Adedoja ${ }^{\mathrm{b}}$, Sjirk Geerts ${ }^{\mathrm{b}}$, Ernita van Wyk ${ }^{\mathrm{c}, \mathrm{d}}$, J. Stephen Boatwright ${ }^{\mathrm{a}, *}$ \\ ${ }^{a}$ Department of Biodiversity and Conservation Biology, University of the Western Cape, Private Bag x17, Bellville, 7535, Cape Town, South Africa \\ ${ }^{\mathrm{b}}$ Department of Conservation and Marine Sciences, Cape Peninsula University of Technology, P.O. Box 652, Cape Town 8000, South Africa \\ ${ }^{\mathrm{c}}$ South African National Biodiversity Institute, Private Bag X7, Newlands, 7735, Cape Town, South Africa \\ ${ }^{\mathrm{d}}$ Institute for Coastal and Marine Research, Nelson Mandela University, P.0. Box 77000, Gqeberha, 6301, South Africa
}

\section{A R T I C L E I N F O}

\section{Article History:}

Received 22 June 2021

Revised 9 September 2021

Accepted 10 September 2021

Available online xxx

Edited by Dr. S.J. Siebert

Keywords:

Core Cape Floristic Region

Canopy cover

Invasion

Litter depth

Plant height

\begin{abstract}
A B S T R A C T
The influence of invasive alien plants on plant community structure and above ground biomass in their novel range is poorly understood, as the magnitude and direction of these effects are often species and ecosystem specific. Here we compared community metrices of native plants and soil properties between study sites invaded by Hakea drupacea, uninvaded sites and cleared sites (sites formerly invaded by $H$. drupacea). A total of 129 plant species belonging to 75 genera were recorded across all study sites. Invasive Acacia saligna, A. longifolia, A. cyclops (Fabaceae) and Leptospermum laevigatum (Myrtaceae) co-occurred with H. drupacea in the invaded sites. Overall plant species richness, which constituted higher number of native plant species, was recorded in uninvaded sites compared to invaded and cleared sites. Plant species composition was similar between uninvaded and cleared sites, but species composition recorded in uninvaded and cleared sites were significantly different from species composition recorded at invaded sites. Litter depth was significantly higher in invaded sites compared to uninvaded and cleared sites. Hakea drupacea did not affect soil properties in invaded sites. Here we show that $H$. drupacea probably reduces the diversity of native plant species especially in invaded sites probably through the effect of litter production and canopy cover, pointing to a beneficial effect of removal of $H$. drupacea. We encourage active restoration of sites invaded by $H$. drupacea at early stages of invasion before the plants become established and suppress the growth of native species.
\end{abstract}

(C) 2021 SAAB. Published by Elsevier B.V. All rights reserved.

\section{Introduction}

Biological invasion is one of the leading factors driving biodiversity loss through a direct effect on community structure and composition (Belnap and Philips 2001; Mangachena and Geerts 2017, Mangachena and Geerts 2019; Le Roux et al., 2020), as well as modification of ecosystem processes at various scales (Ehrenfeld 2003; Levine et al., 2003). Invasive alien plant species (IAPs) are often characterized by traits and ecophysiological functions such as high growth rate and deep roots (Liao et al., 2008; Morris et al., 2020), which aid the ability of IAPs to invade new ecosystems and out-compete native species. Since species traits may influence ecosystem processes (Hobbie 1992; Van Breemen and Finzi 1998), IAPs may alter soil properties and biogeochemical cycles (Ehrenfeld and Scott, 2001) as well as other abiotic conditions that typically impact the growth of both native and invasive alien species in invaded areas (Wilson et al. 2020).

\footnotetext{
* Corresponding author.

E-mail address: jboatwright@uwc.ac.za (J.S. Boatwright).
}

Above ground biomass and ecosystem net primary productivity often increase in invaded versus uninvaded areas (Ehrenfeld 2003) due to altered nitrogen fixation rates and increased litter decomposition in invaded areas. While research has addressed changes in soil carbon and nitrogen, little attention has been paid to other soil elements (but see Blank and Young 2002; 2004; Stefanowicz et al., 2017) and how these influence the growth and development of native species. In a review by Hirsch et al. (2020), they indicated that while soil pH reduced significantly in areas invaded by Eucalyptus camaldulensis Dehnh., there was a significant increase in litter accumulation as well as changes in soil hydrological properties. These modifications to soil elements and other environmental components often result in a decline in the development and diversity of native species in invaded areas (Kerr and Ruwanza, 2016; Hirsch et al., 2020). In the Core Cape Floristic Region (CCFR) of South Africa, where the dominant native plant species are shrubs, the presence of invasive alien trees and shrubs may have a significant and varied impact on different soil elements as well as other abiotic conditions in different vegetation types in this region.

The CCFR - one of the richest biodiversity hotspots in the world is home to over 9300 plant species (Linder 2005; Goldblatt and 
Manning 2002, Manning and Goldblatt 2012), 68\% of which are endemic to the region (Manning and Goldblatt, 2012). Most of the flowering plants in the fynbos biome of the CCFR depend on fire at specific intervals for reproduction (Bond and van Wilgen, 1996). Also, fire is critical for the recycling of soil nutrients (Le Maitre and Midgley, 1992) and this partly influences species distribution in the CCFR. Biological invasion is one of the major threats to native plant diversity in the CCFR (Le Maitre et al., 2000) as up to $70 \%$ of the natural fynbos range is invaded by alien plants (Rouget et al., 2003). Invasive species of the genus Hakea Schrad. \& J.C.Wendl. (H. drupacea (C.F. Gaertn.) Roem. \& Schult., H. gibbosa Cav. and H. sericea Schrad. \& J.C. Wendl.), are native to Australia and were introduced to South Africa between 1840 and 1860 (Shaughnessy, 1986; Richardson et al., 1987). Fire aids the spread of Hakea in this ecosystem as all three invasive Hakea species rely on fire for seed regeneration and dispersal (Richardson et al., 1987). In contrast, the spread of the naturalized H. salicifolia (Vent.) B.L.Burtt is not driven by fire (Moodley et al., 2014, Moodley et al., 2016). Invasive alien Proteaceae, especially Hakea, have larger seed banks and higher seed dispersal rates compared to native Proteaceae (Richardson et al., 1987). This contributes to the success of alien Hakea species in the CCFR and consequently this genus is the only Proteaceae genus overrepresented (Moodley et al., 2013). Also, invasive Hakea species are well adapted to the nutrient poor soil of the CCFR (Wilson et al., 2020), which also aid their persistence in this region.

Hakea drupacea, formerly known as H. suaveolens R.Br., was introduced to South Africa as a hedge plant to prevent animals from entering pine plantations and to stabilize sand dunes on the Cape Flats (Fugler, 1982). This invasive alien plant species is classified as a category $1 \mathrm{~b}$ invader under the current NEM:BA regulations (NEM: BA 2016). It is a localized and abundant invader (Rouget et al., 2004) that forms dense, impenetrable stands that can suppress native vegetation (Fugler, 1982; Richardson and Van Wilgen, 2004; Erckie, 2014). Hakea drupacea is a granite specialist with a limited distribution range compared to the more widespread generalist congeners that occur mostly on the sandstone-derived soils (Wilson et al., 2020). H. drupacea is serotinous, has two-winged seeds that are covered in woody capsules and they are primarily dispersed by wind. Similar to $H$. salicifolia and unlike the more widespread $H$. sericea and $H$. gibbosa that have been studied extensively in this region (van Wilgen and Richardson, 1985; Richardson 1985; Richardson et al., 1987; Kluge and Neser, 1991, Gordon and Fourie 2011), H. drupacea has received little or no research attention, and the impact of this species on ecosystem soil properties and native vegetation structure is largely unknown. This may be because $H$. drupacea is the Hakea with the smallest distribution range in the CCFR (Richardson et al., 1987). However, fynbos generally occurs on low-nutrient soil (Wilson et al., 2020) and H. drupacea could expand its ecological range in low-nutrient soil if left unchecked.

Here we investigate whether the presence of $H$. drupacea affects native plant species richness, litter depth as well as the soil properties of invaded areas compared to uninvaded and cleared areas. Specifically, we aimed to determine whether: (1) $H$. drupacea abundance influences species richness and composition of native fynbos and other alien plant communities? (2) the height and canopy cover of $H$. drupacea influences leaf litter production; and (3) $H$. drupacea alters soil chemical and physical properties in invaded areas.

\section{Materials and Methods}

\subsection{Study area}

This study was conducted at 12 sites across the invasive range of $H$. drupacea within the Cape Peninsula and the Overberg region of the Western Cape Province, South Africa (Fig 1, Supplementary Table 1).
The area experiences a Mediterranean-type climate with hot dry summers and cold wet winters. Average annual rainfall is about $300 \mathrm{~mm}$ of which most falls during winter months (Lamprecht et al., 2006). The mean maximum temperature ranges between $15^{\circ} \mathrm{C}$ and $27^{\circ} \mathrm{C}$ for the cool and warm months, respectively. Soils of this region are classified as well-drained, acidic and nutrient-poor (Rebelo et al., 2006).

\subsection{Experimental design}

Twelve plots each measuring $5 \times 5 \mathrm{~m}\left(25 \mathrm{~m}^{2}\right)$ were located in invaded and adjacent uninvaded sites (Supplementary Table 1). Due to low availability of cleared sites near invaded and uninvaded sites for comparative purposes, only three plots represented cleared sites, comprising a total of 27 study plots for invaded, uninvaded and cleared sites following Barney et al. (2015). Invaded sites referred to those predominantly invaded by $H$. drupacea with a cover of at least $50 \% \mathrm{H}$. drupacea and uninvaded sites constituted sites where $\mathrm{H}$. drupacea was absent. Invaded sites considered were those with established invasions since impacts could be assessed with a higher level of confidence (Tererai et al., 2013). But due to lack of sites with established $H$. drupacea invasions, three more recently invaded sites were included. In cases where a site free of $H$. drupacea could not be obtained, few H. drupacea individuals were allowed to occur in uninvaded plots with low percentage cover (1-5\%), since IAPs at such low density have little or no effects upon native vegetation composition and structure (Hejda and Pyšek, 2006; Catford et al., 2012). Cleared sites referred to recovered sites where $H$. drupacea and other alien plants had been removed.

Sites had similar ecological conditions i.e. similar topography (altitude, slope, aspect), vegetation, soil type and land-use history (Hejda and Pyšek, 2006; Barney et al., 2015). A distance ranging between $20 \mathrm{~m}$ and $50 \mathrm{~m}$ was maintained between invaded and uninvaded plots. This ensured that uninvaded or cleared plots were not affected by impacts such as shade from the invader.

\subsection{Vegetation survey}

Vegetation surveys were conducted on all study sites between July and November 2016. For each site, plots of $5 \times 5 \mathrm{~m}$ were temporarily demarcated using a measuring tape and plot corners marked with steel rods. The centroid of each plot was marked using a handheld Global Positioning System (Garmin GPS map 60CSx).

All individual plant species encountered in each plot were counted and identified up to species level where possible (Supplementary Table 2). They were assigned to their origin status (alien or native) and growth forms (see Mangachena and Geerts, 2019). We classified both native and alien plant species as trees, shrubs, creepers, herbs, geophytes and graminoids (sedges, grasses and restioids (plants belonging to family Restionaceae)). Plant specimens that could not be identified in the field were pressed for identification at the Compton Herbarium, Kirstenbosch Botanical Gardens. A measuring tape was used to measure the height of all plant species and that of large trees were visually estimated. Woody plants found along plot margins were included if any of their parts fell inside the plot. In such cases, only the height of the part found in the plot was measured. For multi-stemmed plants, only the height of the tallest stem was recorded. Percentage canopy cover for each woody plant species was visually estimated and the level of invasion for each plot was characterized by the percentage cover of $H$. drupacea. Percentage cover for grasses was estimated according to Braun-Blanquet (1932) cover classes as follows: 5: 75-100\%; 4: 50-75\%; 3: 25-50\%; 2: 5-25\%; 1: 1$5 \%$ cover. We recorded the presence and absence of leaf litter and estimated the depth of accumulated leaf litter in five subsamples per plot (Barney et al., 2015). 


\subsection{Soil sampling}

Soil sampling was done at the same time and on the same plots as the vegetation survey. Five soil samples from four edges and the center of each plot were collected. Soil was sampled following 48 hours without rain (Barney et al., 2015). Any surface litter present was removed, and the top $10 \mathrm{~cm}$ of the soil was collected with a standard soil auger. Soil samples from each plot were combined and mixed thoroughly to form a bulk sample for the plot. Soil was sieved with a $2 \mathrm{~mm}$ mesh to remove large particles and stones. Smaller fragments and debris were removed by hand. Representative soil samples of $500 \mathrm{~g}$ for each plot were placed in labelled, clean, air-proof polythene plastic bags.

Soil samples were analysed for soil texture, soil moisture, $\mathrm{pH}_{\mathrm{KCL}}$, organic carbon $(\mathrm{C})$, nitrogen $(\mathrm{N})$, phosphorus $(\mathrm{P})$, potassium $(\mathrm{K})$, calcium $(\mathrm{Ca})$, magnesium $(\mathrm{Mg})$ and sodium $(\mathrm{Na})$. Nitrogen content was determined following the Kjeldahl method (Bremner \& Mulvaney 1982). Phosphorus, K, Ca, Mg, Na and C were determined by using $1 \%$ citric acid. We weighed and oven-dried soil samples at $105^{\circ}$ $\mathrm{C}$ for 48 hours and re-weighed to obtain percent soil moisture. The soil analysis was carried out at the Western Cape Department of Agriculture, Elsenburg Laboratory, following standard procedures used by member laboratories of the inter-laboratory control scheme Agri Laboratory Association of Southern Africa (AgriLASA) and methods of the Association of Official Analytical Chemists (AOAC).

\subsection{Data analysis}

The Shapiro-Wilk's test was performed on all data to test for normality assumptions. Species richness and composition, as well as litter depth were the main response variables with invasion as the main factor. Species richness was calculated as the number of plant species per sampling plot. The differences in plant species richness between invaded $(n=12)$, uninvaded $(n=12)$ and cleared $(n=3)$ sites was tested using one-way ANOVA as species richness conformed to normality assumptions. Species richness of alien plants and litter depth did not fit normal distributions and thus, we conducted a nonparametric Kruskal-Wallis test to determine differences in species richness of alien plant species between invaded, uninvaded and cleared sites. A Dunn's test was used to determine significance among paired study sites.

We also conducted a non-parametric Kruskal-Wallis test to determine differences in litter depth between invaded, uninvaded and cleared sites. The relationship between litter depth and canopy cover of $H$. drupacea in invaded sites was tested using a linear regression. To determine differences in percentage canopy cover between invaded and uninvaded sites, we conducted a Mann-Whitney U test. Similarly, a Mann-Whitney U test was used to determine differences in height of H. drupacea and dominant native species in uninvaded sites.

To assess differences in plant species composition among invaded, uninvaded and cleared sites, we used non-metric multi-dimensional

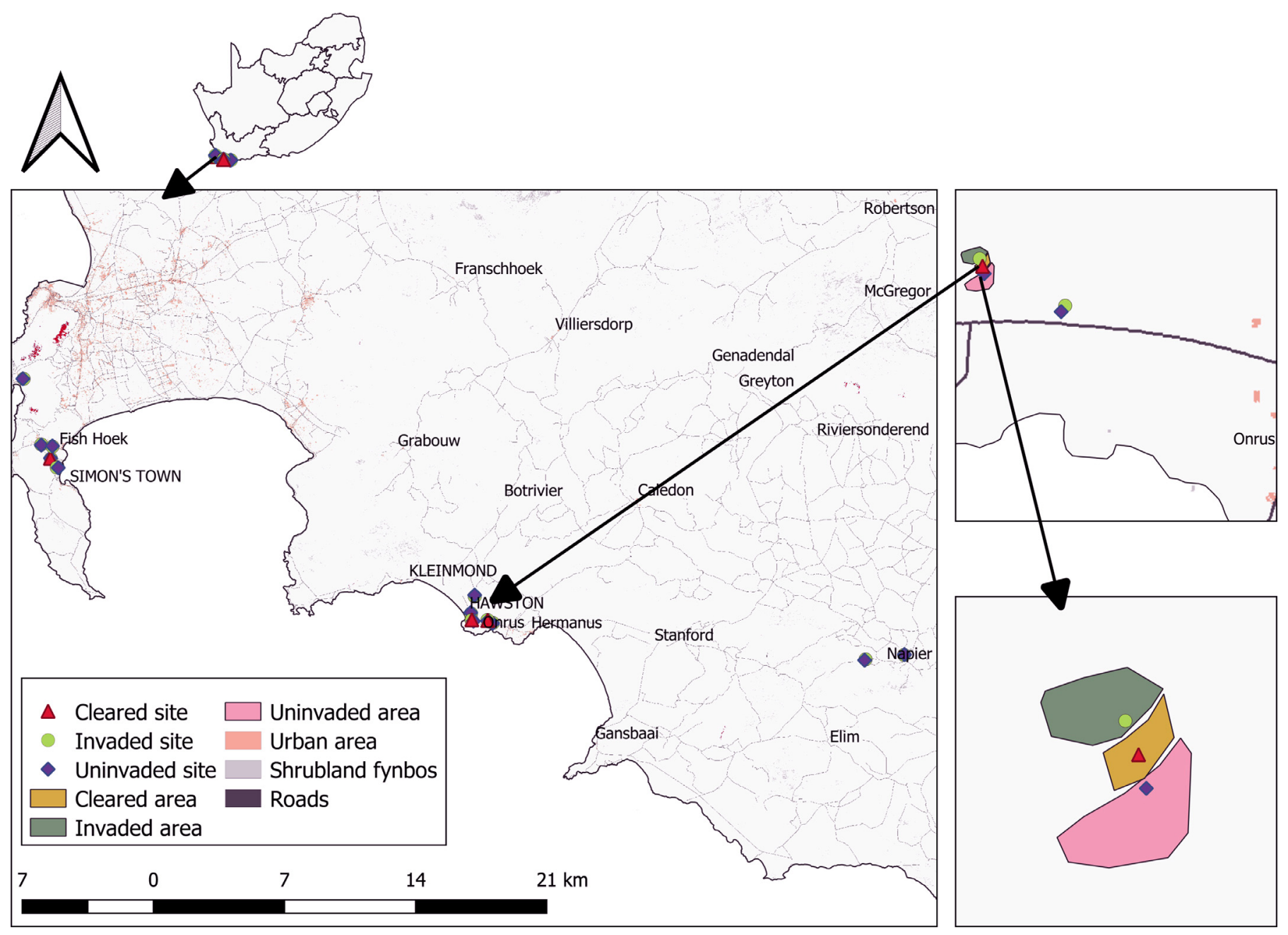

Fig 1. Study area and distribution of study sites with detailed example of invaded, uninvaded and cleared plot area 
scaling ordination (nMDS) with the "vegan" package in R. Permutation Analysis of Variance (PERMANOVA) with 999 permutation was conducted to compare among-group similarities and assess significance by permutation. PERMANOVA was conducted using the Jaccard similarity index obtained from species presence/absence data. All analysis were conducted using R version 3.6.1 (R Core Team, 2017).

\section{Results}

A total of 129 plant species belonging to 35 families and 75 genera were recorded (Supplementary Table 2). 49 plant species were recorded in invaded sites, 94 plant species in the uninvaded sites and 27 species in the cleared sites. Species recorded in invaded sites comprised of 41 (84\%) native and 8 (16\%) alien, while $89(95 \%)$ native and 5 (5\%) alien were recorded in uninvaded sites and 26 (96\%) native and $1(4 \%)$ alien plant species were recorded in cleared sites. Percentage ground cover of native shrubs and creepers were higher in uninvaded sites, while alien trees dominated the invaded sites and native shrubs increased significantly in cleared sites (Fig. 2a).

The two most dominant plant species in uninvaded and cleared sites were Passerina corymbosa Eckl. ex C.H.Wright (Thymelaeaceae) and Erica L. species (Ericaceae) but were absent in sites with low invasion where $H$. drupacea (1-5\% cover) occurred. A native species, Colpoon compressum P.J. Bergius co-existed mostly with the invasive
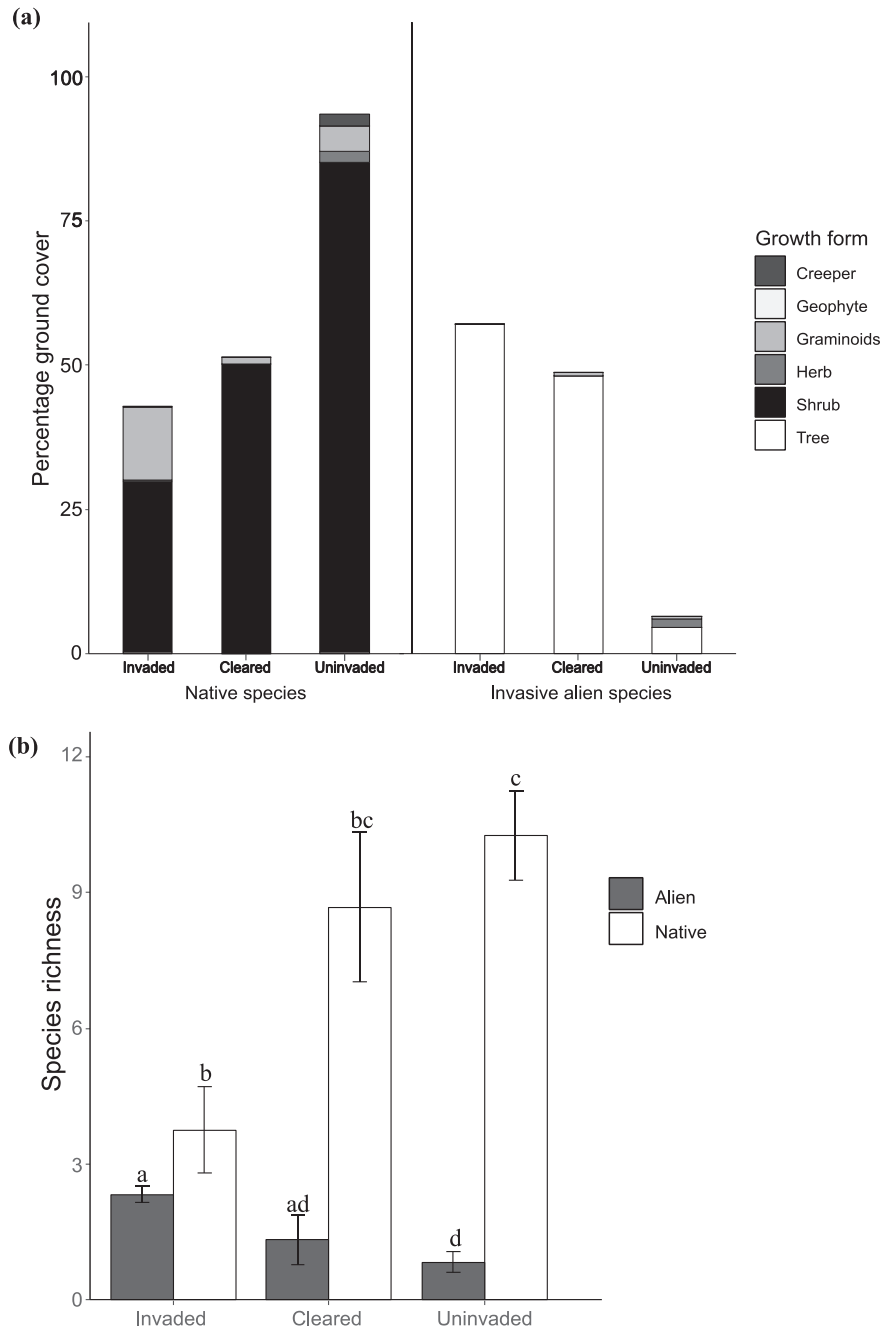

Fig 2. (a) Differences in growth forms and (b) mean \pm (SE) species richness of native and invasive alien plants recorded among invaded, cleared and uninvaded sites. Bars with different alphabet are significantly different at $\mathrm{P}<0.05$.
H. drupacea. Few stands of other IAPs including Acacia saligna (Labill.) H.L.Wendl., A. longifolia (Andr.) Willd., A. cyclops A.Cunn. ex G.Don (Fabaceae) and Leptospermum laevigatum (Gaertn.) F.Muell. (Myrtaceae) co-occurred with $H$. drupacea in the invaded sites.

There was a significant difference in plant species richness among the study sites $\left(F_{2,24}=6.217, P=0.007\right.$, Fig. $\left.2 b\right)$, specifically between the invaded and uninvaded sites $(P=0.006)$ following post-hoc test. Higher species richness of native plants was recorded in uninvaded sites compared to invaded sites $\left(F_{2,24}=10.31, P=0.0006\right)$. Also, higher species richness of IAPs was recorded in invaded sites compared to uninvaded and cleared sites (Kruskal-Wallis Chi squared $=12.701$, $P=0.002, \mathrm{df}=2$ ).

Litter depth was significantly lower in uninvaded sites $(1.48 \pm 0.1$ $\mathrm{cm})$ and cleared sites $(0.27 \pm 0.05 \mathrm{~cm})$ compared to invaded sites $(11.55 \pm 1.4 \mathrm{~cm})$ where litter depth was almost 5 times that of uninvaded sites (Kruskal-Wallis Chi Square $=19.63, P<0.0001$, $\mathrm{df}=2$, Fig. 3). There was no significant difference in litter depth between cleared and uninvaded sites.

When we compared the height of $H$. drupacea in invaded sites with the height of dominant native plant species in uninvaded sites, H. drupacea in invaded sites (mean $( \pm \mathrm{SE})=3.05 \pm 0.34,4.1 \mathrm{~m}-0.9 \mathrm{~m})$ was significantly taller than dominant native plant species (mean $( \pm \mathrm{SE})=0.73 \pm 0.11,1.5 \mathrm{~m}-0.25 \mathrm{~m})$ in uninvaded sites (Mann-Whitney $U$ test $=138, P<0.001)$. In invaded sites, there was a significant difference in the height of $H$. drupacea compared to other invasive alien plant species (mean $( \pm$ SE $)=1.94 \pm 0.39,6.13 \mathrm{~m}-0.25 \mathrm{~m})$, with $H$. drupacea dominating in height compared to other IAPs in invaded sites $(\mathrm{t}=2.11, P=0.045, \mathrm{df}=26)$.

There was a significant difference in canopy cover of $H$. drupacea in invaded sites compared to dominant native plant species in uninvaded sites (Mann-Whitney $U$ test $=6, P=0.0002$ ), as the percentage canopy cover for $H$. drupacea (mean $( \pm \mathrm{SE})=63.33 \pm 6.7,90 \%-20 \%$ ) in invaded sites was significantly higher than canopy cover of dominant native species (mean $( \pm \mathrm{SE})=11.75 \pm 3.04,30 \%-1 \%)$ in uninvaded sites.

There was a significant difference in plant species composition among the study sites (PERMANOVA $F_{2,24}=3.698, P=0.001$ ), specifically between uninvaded and invaded sites $(P=0.003)$ as well as between invaded and cleared sites $(P=0.012)$. nMDS showed two

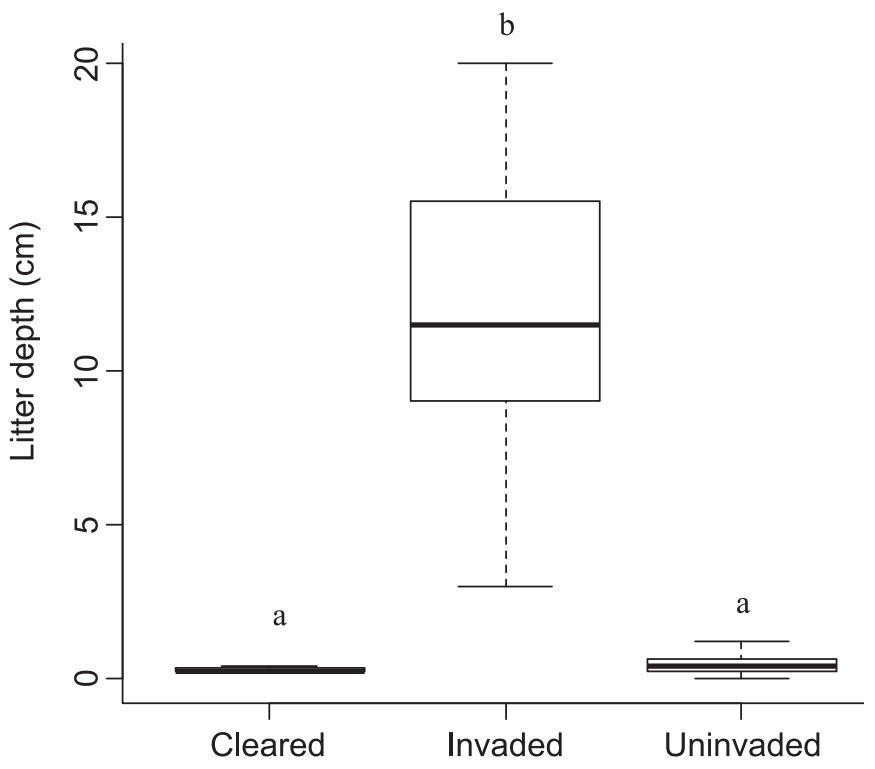

Fig 3. Differences in litter depth between invaded and uninvaded sites. Boxplots display the median with a solid line, 25th and 75th percentiles in the lower and upper boxes, respectively, and the data range is indicated by the whiskers. Bars with different alphabet are significantly different at $\mathrm{P}<0.05$. 


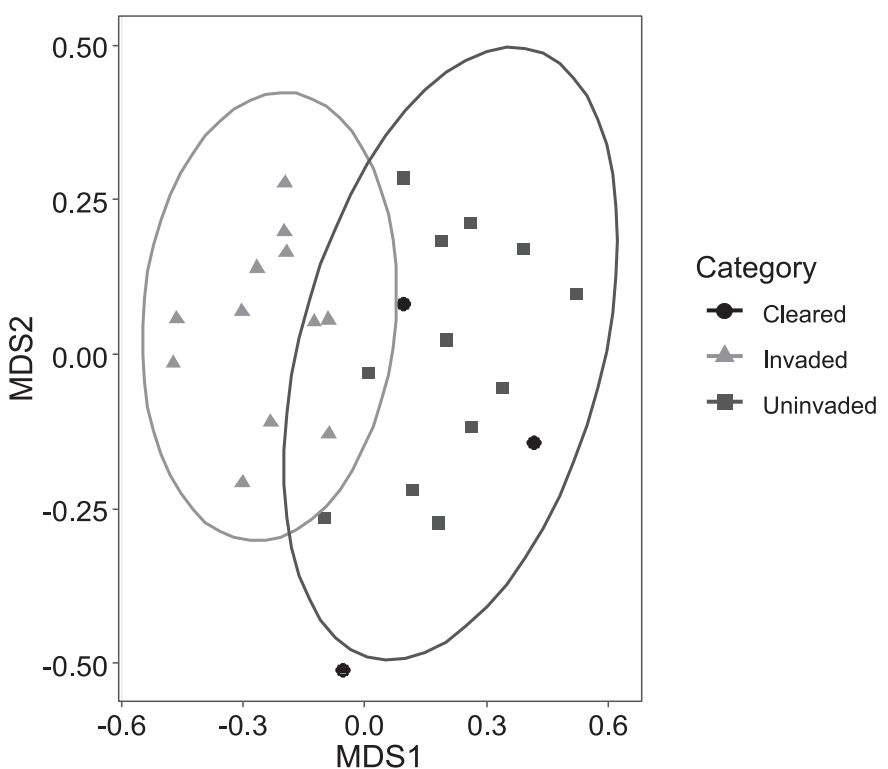

Fig 4. nMDS showing differences in species composition among invaded, uninvaded and cleared sites. Species presence/absence data was used to test for similarity (Jaccard index).

\section{Table 1}

Means \pm (SE) of soil chemical properties in Hakea drupacea invaded sites and adjacent uninvaded sites.

\begin{tabular}{llllll}
\hline Soil properties & Invaded & Uninvaded & df & t-value & $P$ \\
\hline Moisture & $8.54 \pm 2.19$ & $6.23 \pm 1.58$ & 22 & 0.87 & 0.395 \\
Acidity & $1.22 \pm 0.14$ & $1.06 \pm 0.07$ & 13 & 1.02 & 0.328 \\
$\mathrm{pH}$ & $5.33 \pm 0.32$ & $5.39 \pm 0.27$ & 22 & 0.14 & 0.89 \\
Carbon & $2.33 \pm 0.25$ & $1.65 \pm 0.22$ & 22 & 2.008 & 0.057 \\
Calcium & $11.32 \pm 5.00$ & $8.66 \pm 4.19$ & 22 & 0.407 & 0.688 \\
Magnesium & $1.79 \pm 0.23$ & $1.45 \pm 0.16$ & 22 & 1.22 & 0.24 \\
Phosphorus & $9.5 \pm 2.79$ & $8.42 \pm 1.76$ & 22 & 0.89 & 0.38 \\
Potassium & $79.08 \pm 10.88$ & $59.08 \pm 9.38$ & 22 & 1.39 & 0.18 \\
Sodium & $136 \pm 13.56$ & $88.25 \pm 29.84$ & 22 & 1.32 & 0.2 \\
Nitrogen & $0.11 \pm 0.02$ & $0.09 \pm 0.02$ & 22 & 0.66 & 0.52 \\
\hline
\end{tabular}

cleared sites grouped with uninvaded sites and a clear separation between uninvaded and invaded sites (Fig. 4).

\subsection{Soil properties}

There was no significant difference in soil properties between invaded and uninvaded sites (Table 1). Carbon was slightly higher in invaded compared to uninvaded sites, but this was not statistically significant.

\section{Discussion}

Here we show that $H$. drupacea significantly reduces native plant species richness in invaded sites, forms a denser canopy and increases litter depth. In a largely treeless ecosystem, like the CCFR, where the dominant native species are shrubs, the presence of invasive alien trees with dense canopies may reduce direct sunlight reaching the understory, impacting the growth and reproduction of understory native vegetation. In a review by Valladares et al. (2016), they highlighted mechanisms by which shade negatively impact the recruitment of plants, especially when reduced irradiance severely limits understory photosynthesis. Also, alien species from regions with similar climates have stronger impacts on native species in invaded areas (Gaertner et al., 2009). For example, the Australian Acacia Mill. species account for the highest decline in native plant species in South Africa (Gaertner et al., 2009). Since H. drupacea is native to
Australia - a Mediterranean type ecosystem with similar climate as the CCFR - it is therefore not surprising that native species richness declined significantly in $H$. drupacea invaded areas in the present study.

Habitat restoration through active clearing of $H$. drupacea improved the recovery of native species as plant species composition in cleared sites were similar to those in uninvaded sites, and species composition in cleared and uninvaded sites were significantly different from invaded sites. This suggests restoration of invaded sites can reduce the negative effect of $H$. drupacea on native plant species. Although we did not observe $H$. drupacea on any of the cleared sites, a few stands of Acacia saligna and Leptospermum laevigatum were recorded on one of the cleared sites as were a number of secondary invaders (Nsikani et al., 2020). Since $H$. drupacea spreads rapidly and alters abiotic conditions of invaded areas, changes in environmental condition such as precipitation, temperature, litter cover and soil nutrients may aid the development and spread of other IAPs in invaded areas. This will amplify the impacts of IAPs on native plant communities (Simberloff, 2006; O'Loughlin and Green, 2017), causing a further decline in the diversity and distribution of native species in invaded ecosystems.

Litter cover is one of the main factors hindering the growth of understory vegetation in areas with high canopies (Williams and Wardle, 2007; Mitchell et al., 2011; Dostál et al., 2013; BravoMonasterio et al., 2016). Olson and Wallander (2002) defined a litter depth of $5-10 \mathrm{~cm}$ as the limit for the recruitment of other species. In this study, a thick litter layer averaging $11.55 \pm 1.4 \mathrm{~cm}$ was observed under $H$. drupacea stands, reaching up to $20 \mathrm{~cm}$ in some invaded sites. This is 2-4 times thicker than the defined limits for the recruitment of other plant species, especially in the fynbos. The accumulation of litter in the understory of $H$. drupacea could partly explain the declining plant species richness in invaded sites compared to uninvaded sites where litter depth is lower. A thick litter layer in the understory of IAPs reduces the access of understory vegetation to light and water, as well as reduces seed access to substrate for germination and growth (Olsen and Wallander, 2002; Hata et al., 2010). Also, litter depth increased with the height of $H$. drupacea in this study, which implies that litter depth is expected to increase with $H$. drupacea stand age. This may increase the biomass of flammable materials and accumulation of fuel loads in the invaded areas. The frequency and severity of wildfire is expected to increase in regions with Mediterranean climates due to predicted warmer and drier climates (Gitay et al., 2001). Increasing fuel loads from $H$. drupacea and other litter producing IAPs in the CCFR may further enhance fire frequency and severity in this region. This in turn might enhance the spread of $H$. drupacea and impact native species (Vlok and Yeaton, 2000; Geerts et al., 2013).

Litter cover also influences soil properties and other abiotic factors in areas invaded by alien trees or shrubs (Prescott 2002). Here, we found no significant difference in soil nutrient composition between invaded and uninvaded areas. This contrasts findings for some nitrogen-fixing alien trees like the Australian Acacia species, or creepers such as Pueraria montana (Thunb.) Merr. (kudzu vine) that change soil properties of the colonized range (Van Der Waal, 2009; Geerts et al., 2016). A recent meta-analysis by Zhang et al. (2018) showed that IAPs may support more decomposers that subsequently aid the release of nutrients through litter pathways, and also enhance nutrient uptake by forming more symbiosis in the rhizosphere. This process may take a considerable amount of time to develop and also depends on the quantity of litter produced that differ among IAPs (Medina-Villar et al., 2016). Invasion of $H$. drupacea in our study sites may be too early to cause significant effects on soil nutrients, as some invaded sites were only recently invaded by $H$. drupacea. We observed a slight increase in soil carbon in invaded sites compared to uninvaded sites in this study, although this was not statistically significant. Other studies have also reported higher soil organic carbon 
in the understory of invaded sites compared to open uninvaded sites (Mugunga and Mugumo, 2013; Zhang et al., 2018). This is mostly attributed to the influence of shade from the canopy of IAPs stimulating the decomposition of litter and release of soil carbon and other soil chemical components (Prescott, 2002). A longer invasion period of $H$. drupacea will increase canopy cover and litter production in invaded areas, and will most likely enhance the magnitude of the effects of $H$. drupacea on soil properties.

In conclusion, $H$. drupacea significantly reduced the diversity of native plant species in invaded sites. This is one of the few studies that have assessed the effects of $H$. drupacea on above ground community structure and soil properties (Cilliers et al., 2004). While active clearing may restore native species in previously invaded areas, $H$. drupacea may facilitate the growth of other IAPs that may be more resilient to habitat restoration. Therefore, we encourage active removal of invasive $H$. drupacea at an early stage of invasion before they become established where they facilitate other IAPs and produce a thick litter layer to suppress the development of native species in their colonized range.

\section{Declaration of Competing Interest}

The authors declare that they have no known competing financial interests or personal relationships that could have appeared to influence the work reported in this paper.

\section{Acknowledgements}

The South African Department of Forestry, Fisheries and the Environment (DFFtE) are thanked for funding, noting that this publication does not necessarily represent the views or opinions of DFFtE or its employees. We thank the two anonymous reviewers whose comments improved the manuscript.

\section{Supplementary materials}

Supplementary material associated with this article can be found, in the online version, at doi:10.1016/j.sajb.2021.09.017.

\section{References}

Barney, J.N., Tekiela, D.R., Barrios-Garcia, M.N., Dimarco, R.D., Hufbauer, R.A., Leipzig-Scott, P., Nunez, M.A., Pauchard, A., Pyšek, P., Vítková, M., Maxwell, B.D., 2015. Global Invader Impact Network (GIIN): toward standardized evaluation of the ecological impacts of invasive plants. Ecol. Evol. 5, 2878-2889. https://doi.org/ 10.1002/ece3.1551.

Belnap, J., Phillips, S.L., 2001. Soil biota in an ungrazed grassland: response to annual grass (Bromus tectorum) invasion. Ecol. Appl. 11, 1261-1275. https://doi.org/ 10.1890/1051-0761(2001)011[1261:SBIAUG]2.0.CO;2.

Blank, R.R., Young, J.A., 2002. Influence of the exotic invasive crucifer, Lepidium latifolium, on soil properties and elemental cycling. Soil Sci. 167, 821-829.

Blank, R.R., Young, J.A., 2004. Influence of three weed species on soil nutrient dynamics. Soil Sci. 169, 385-397.

Bond, W.J., van Wilgen, B.W., 1996. Surviving fires-vegetative and reproductive responses. Fire and plants. Springer, Dordrecht, pp. 34-51.

Bravo-Monasterio, P., Pauchard, A., Fajardo, A., 2016. Pinus contorta invasion into treeless steppe reduces species richness and alters species traits of the local community. Biol. Invasions 18, 1883-1894. https://doi.org/10.1007/s10530-016-1131-4.

Braun-Blanquet, J., 1932. Plant sociology. The study of plant communities. Plant Sociology. The study of plant communities. First ed.

Bremner, J.M., Mulvaney, C.S., 1982. Salicylic acid-thiosulphate modification of Kjeldahl method to include nitrate and nitrite. Agronomy 9, 621-622.

Cilliers, C.D., Esler, K.J., Boucher, C., Brown, N.A.C., 2004. Effects of alien plant management and fire on soil seed banks and regeneration in the Cape Peninsula National Park, South Africa. South Africa J. Bot. 70, 705-712.

Catford, J.A., Vesk, P.A., Richardson, D.M., Pyšek, P., 2012. Quantifying levels of biological invasion: towards the objective classification of invaded and invasible ecosystems. Global Change Biol. 18, 44-62. https://doi.org/10.1111/j.13652486.2011.02549.x.

Dostál, P., Müllerová, J., Pyšek, P., Pergl, J., Klinerová, T., 2013. The impact of an invasive plant changes over time. Ecol. Lett. 16, 1277-1284. https://doi.org/10.1111/ ele.12166.
Ehrenfeld, J.G., 2003. Effects of exotic plant invasions on soil nutrient cycling processes. Ecosystems 6, 503-523. https://doi.org/10.1007/s10021-002-0151-3.

Ehrenfeld, J.G., Scott, N., 2001. Invasive species and the soil: effects on organisms and ecosystem processes. Ecol. Appl. 11, 1259-1260. https://doi.org/10.1890/10510761(2001)011[1259:ISATSE]2.0.CO;2.

Erckie, L. 2014. Assessing the invasiveness of Hakea drupacea (Proteaceae) in the Western Cape Province. Unpublished Honours Thesis University of the Western Cape.

Fugler, S.R., 1982. Infestations of three Australian Hakea species in South Africa and their control. South Africa For. J. 120, 63-68.

Gaertner, M., Den Breeyen, A., Hui, C., Richardson, D.M., 2009. Impacts of alien plant invasions on species richness in Mediterranean-type ecosystems: a meta-analysis. Prog. Phys. Geog. 33, 319-338.

Geerts, S., Moodley, D., Gaertner, M., Le Roux, J.J., McGeoch, M., Muofhe, C., Richardson, D.M., Wilson, J.R.U., 2013. The absence of fire can cause a lag phasethe invasion dynamics of Banksia ericifolia (Proteaceae). Austral. Ecol. 38, 931-941.

Geerts, S., Mashele, B.V., Visser, V., Wilson, J.R.U., 2016. Lack of human assisted dispersal means Pueraria montana var. lobata (kudzu vine) could still be eradicated from South Africa. Biol. Invasions 18, 3119-3126.

Gitay, H., Brown, S., Easterling, W., Jallow, B., Antle, J., Apps, M., ..., White, K.S., 2001 Ecosystems and their goods and services. Impacts, adaptation, and vulnerability. Contribution of Working group II to the Third Assessment Report of the Intergovernmental Panel on Climate Change. Cambridge University Press, pp. 235-342.

Goldblatt, P., Manning, J.C., 2002. Plant diversity of the Cape region of southern Africa. Ann. Missouri Bot. Garden 89, 281-302.

Gordon, A.J., Fourie, A., 2011. Biological control of Hakea sericea Schrad. \& JC Wendl. and Hakea gibbosa (Sm.) Cav.(Proteaceae) in South Africa. Africa Entomol. 19, 303-314.

Hata, K., Kato, H., Kachi, N., 2010. Litter of an alien tree, Casuarina equisetifolia, inhibits seed germination and initial growth of a native tree on the Ogasawara Islands (subtropical oceanic islands). J. For. Res. 15, 384-390. https://doi.org/10.1007/ s10310-010-0199-4.

Hejda, M., Pyšek, P., 2006. What is the impact of Impatiens glandulifera on species diversity of invaded riparian vegetation? Biol. Conserv. 132, 143-152.

Hirsch, H., Allsopp, M., Canavan, S., Cheek, M., Geerts, S., Geldunhuys, C.J., Harding, G. Hurley, B.P., Jones, W., Keet, J.H., Klein, H., Ruwanza, S., van Wilgen, B.W., Wingfield, M.J., Richardson, D.M., 2020. Eucalyptus camaldulensis in South Africa past, present, future. Trans. R. Soc. South Africa 75, 1-22. https://doi.org/10.1080/ 0035919X.2019.1669732.

Hobbie, S.E., 1992. Effects of plant species on nutrient cycling. Trends Ecol. Evol. 7, 336-339. https://doi.org/10.1016/0169-5347(92)90126-V.

Kerr, T.F., Ruwanza, S., 2016. Does Eucalyptus grandis invasion and removal affect soils and vegetation in the Eastern Cape Province, South Africa? Austral. Ecol. 41, 328338. https://doi.org/10.1111/aec.12315.

Kluge, R.L., Neser, S., 1991. Biological control of Hakea sericea (Proteaceae) in South Africa. Agric., Ecosyst. Environ. 37, 91-113.

Lamprecht, S.C., Marasas, W.F.O., Hardy, M.B., Calitz, F.J., 2006. Effect of crop rotation on crown rot and the incidence of Fusarium pseudograminearum in wheat in the Western Cape, South Africa. Australasian Plant Pathol. 35, 419-426. https://doi.org/ 10.1071/AP06040.

Le Maitre, D.C., Midgley, J.J., 1992. Plant reproductive ecology. Ecol. Fynbos: Nutr., Fire Divers. 135-174.

Le Maitre, D. C., Versfeld, D. B., Chapman, R. A., 2000. Impact of invading alien plants on surface water resources in South Africa: A preliminary assessment.

Le Roux, J.J, Clusella-Trullas, S., Mokotjomela, T.M, Mairal, M., Richardson, D.M., Skein, L., Wilson, J.R.U., Weyl, O., Geerts, S. 2020. Biotic Interactions as Mediators of Biological Invasions: Insights from South Africa. In: van Wilgen B., Measey J., Richardson D., Wilson J., Zengeya T. (eds) Biological Invasions in South Africa. Invading Nature - Springer Series in Invasion Ecology, vol 14 pp 387-427. Springer, Cham.

Levine, J.M., Vila, M., Antonio, C.M.D., Dukes, J.S., Grigulis, K., Lavorel, S., 2003. Mechanisms underlying the impacts of exotic plant invasions. Proc. R. Soc. B 270, 775781. https://doi.org/10.1098/rspb.2003.2327.

Liao, C., Peng, R., Luo, Y., Zhou, X., Wu, X., Fang, C., Chen, J., Li, B., 2008. Altered ecosystem carbon and nitrogen cycles by plant invasion: a meta-analysis. New Phytol. 177, 706-714. https://doi.org/10.1111/j.1469-8137.2007.02290.x.

Linder, H.P., 2005. Evolution of diversity: The Cape flora. Trends Plant Sci. 10, 536-541. https://doi.org/10.1016/j.tplants.2005.09.006.

Mangachena, J.R., Geerts, S., 2017. Invasive alien trees reduce bird species richness and abundance of mutualistic frugivores and nectarivores; a bird's eye view on a conflict of interest species in riparian habitats. Ecol. Res. 32, 667-676. https://doi.org/ 10.1007/s11284-017-1481-0.

Mangachena, J.R., Geerts, S., 2019. The absence of keystone indigenous trees inhibits bird recovery up to a decade after invasive tree removal from riparian habitats. Acta Oecologica 101, 103483. https://doi.org/10.1016/j.actao.2019.103483.

Manning, J.C., Goldblatt, P., 2012. Plants of the Greater Cape Floristic Region 1: The Core Cape flora, Strelitzia 29. South African National Biodiversity Institute, Pretoria.

Medina-Villar, S., Rodríguez-Echeverría, S., Lorenzo, P., Alonso, A., Pérez-Corona, E., Castro-Díez, P., 2016. Impacts of the alien trees Ailanthus altissima (Mill.) Swingle and Robinia pseudoacacia L. on soil nutrients and microbial communities. Soil Biol. Biochem. 96, 65-73. https://doi.org/10.1016/j.soilbio.2016.01.015.

Mitchell, M.E., Lishawa, S.C., Geddes, P., Larkin, D.J., Treering, D., Tuchman, N.C., 2011. Time-dependent impacts of cattail invasion in a Great Lakes coastal wetland complex. Wetlands 31, 1143-1149. https://doi.org/10.1007/s13157-011-0225-0.

Moodley, D., Geerts, S., Richardson, D.M., Wilson, J.R.U., 2013. Different traits determine introduction, naturalization and invasion success in woody plants: Proteaceae as a test case. PLoS One 8, e75078. 
Moodley, D., Geerts, S., Rebelo, T., Richardson, D.M., Wilson, J.R.U., 2014. Site-specific conditions influence plant naturalization: The case of alien Proteaceae in South Africa. Acta Oecologica 59, 62-71.

Moodley, D., Geerts, S., Richardson, D.M., Wilson, J.R.U., 2016. The importance of pollinators and autonomous self-fertilization in the early stages of plant invasions: Banksia and Hakea (Proteaceae) as case studies. Plant Biol. 18,124-131.

Morris, T.L., Barger, N.N., Cramer, M.D., 2020. Ecophysiological traits of invasive alien Acacia cyclops compared to co-occuring native species in Strandveld vegetation of the Cape Floristic Region. Austral. Ecol. 45, 48-59. https://doi.org/10.1111/aec.12827.

Mugunga, C.P., Mugumo, D.T., 2013. Acacia sieberiana effects on soil properties and plant diversity in Songa pastures, Rwanda. Int. J. Biodivers. 237525. https://doi. org/10.1155/2013/237525.

National Environmental Management: Biodiversity Act (10/2004), 2016. Draft Alien and Invasive Species Regulations. Department of Environmental Affairs and Tourism. Government Gazette 864 (40166) Pretoria, South Africa.

Nsikani, M.M., Geerts, S., Ruwanza, S., Richardson, D.M., 2020. Secondary invasion and weedy native species dominance after clearing invasive alien plants in South Africa: Status quo and prognosis. South Africa J. Bot. 132, 338-345.

O'Loughlin, L.S., Green, P.T, 2017. Secondary invasion: When invasion success is contingent on other invaders altering the properties of recipient ecosystems. Ecol. Evol. 7, 7628-7637. https://doi.org/10.1002/ece3.3315.

Olson, B.E., Wallander, R.T., 2002. Effects of invasive forb litter on seed germination, seedling growth and survival. Basic Appl. Ecol. 3, 309-317. https://doi.org/ 10.1078/1439-1791-00127.

Prescott, C.E., 2002. The influence of the forest canopy on nutrient cycling. Tree Physiol. 22, 1193-1200. https://doi.org/10.1093/treephys/22.15-16.1193.

R Core Team, 2017. R: A language and environment for statistical computing. R Foundation for Statistical Computing, Vienna, Austria.

Richardson, D.M., 1985. Studies on aspects of the integrated control of Hakea sericea in the south-western Cape Province, South Africa (Master's thesis. University of Cape Town. ).

Richardson, D.M., Van Wilgen, B.W., Mitchell, D.T., 1987. Aspects of the reproductive ecology of four Australian Hakea species (Proteaceae) in South Africa. Oecologia 71, 345-354. https://doi.org/10.1007/BF00378706.

Richardson, D.M., Van Wilgen, B.W., 2004. Invasive alien plants in South Africa: how well do we understand the ecological impacts? Working for Water. South Africa J. Sci. 100, 45-52.

Rebelo, A. G., Boucher, C., Helme, N. A., Mucina, L., Rutherford, M. C., 2006. Fynbos Biome, in: Mucina, L., Rutherford, M. C. (Eds.) The vegetation of South Africa, Lesotho and Swaziland, Strelitzia 19, South African National Biodiversity Institute, Pretoria, pp. 53-219.

Rouget, M., Richardson, D.M., Cowling, R.M., Lloyd, J.W., Lombard, A.T., 2003. Current patterns of habitat transformation and future threats to biodiversity in terrestrial ecosystems of the Cape Floristic Region, South Africa. Biol. Conserv. 112, 63-85.
Rouget, M., Richardson, D.M., Nel, J.L., Le Maitre, D.C., Egoh, B., Mgidi, T., 2004. Mapping the potential ranges of major plant invaders in South Africa, Lesotho and Swaziland using climatic suitability. Divers. Distrib. 10,475-484.

Shaughnessy, G., 1986. Case study of some woody plant introductions to the Cape Town area. In Ecology and management of biological invasions in southern Africa: Proceedings of the National Synthesis Symposium on the Ecology of Biological Invasions/edited by I.A.W. Macdonald, F.J. Kruger, A.A. Ferrar. Cape Town: Oxford University Press.

Simberloff, D., 2006. Invasional meltdown 6 years later: important phenomenon, unfortunate metaphor, or both? Ecol. Lett. 9, 912-919. https://doi.org/10.1111/ j.1461-0248.2006.00939.x.

Stefanowicz, A.M., Majewska, M.L., Stanek, M., Nobis, M., Zubek, S., 2017. Differential influence of four invasive plant species on soil physicochemical properties in a pot experiment. J. Soils Sediments 18, 1409-1423. https://doi.org/10.1007/s11368017-1873-3.

Tererai, F., Gaertner, M., Jacobs, S.M., Richardson, D.M., 2013. Eucalyptus invasions in riparian forests: effects on native vegetation community diversity, stand structure and composition. Forest Ecol. Manag. 297, 84-93. https://doi.org/10.1016/j. foreco.2013.02.016.

Van Breemen, N., Finzi, A.C., 1998. Plant-soil interactions: ecological aspects and evolutionary implications. Biogeochemistry 42, 1-19.

Van der Waal, B.W., 2009. The influence of Acacia mearnsii invasion on soil properties in the Kouga Mountains, Eastern Cape, South Africa (Doctoral dissertation. Rhodes University. ).

Van Wilgen, B.W., Richardson, D.M., 1985. The effects of alien shrub invasions on vegetation structure and fire behaviour in South African fynbos shrublands: a simulation study. J. Appl. Ecol. 955-966.

Valladares, F., Laanisto, L., Niinemets, Ü., Zavala, M.A., 2016. Shedding light on shade: ecological perspectives of understorey plant life. Plant Ecol. Divers. 9, 237-251.

Vlok, J.H.J., Yeaton, R.I., 2000. The effect of short fire cycles on the cover and density of understorey sprouting species in South African mountain fynbos. Divers. Distrib. 6, 233-242. https://doi.org/10.1046/j.1472-4642.2000.00087.x.

Williams, M.C., Wardle, G.M., 2007. Pine and eucalypt litterfall in a pine-invaded eucalypt woodland: the role of fire and canopy cover. Forest Ecol. Manag. 253, 1-10. https://doi.org/10.1016/j.foreco.2007.06.045.

Wilson, J.R., Foxcroft, L.C., Geerts, S., Hoffman, M.T., MacFadyen, S., Measey, J., van Wilgen, B.W., 2020. The role of environmental factors in promoting and limiting biological invasions in South Africa. In Biological Invasions in South Africa. Springer, Cham, pp. 355-385.

Zhang, P., Li, B., Wu, J., Hu, S., 2018. Invasive plants differentially affect soil biota through litter and rhizosphere pathways: a meta-analysis. Ecol. Lett. 22, 200-210. https://doi.org/10.1111/ele.13181. 